\title{
Human Dignity or Social Contract as Normative Frameworks in Applied Ethics?
}

\author{
Maureen Junker-Kenny \\ School of Religion, Trinity College Dublin, Dublin, Ireland \\ mjunkerk@tcd.ie
}

\begin{abstract}
The enquiry whether human dignity as the translation of the biblical designation of the human person as imago Dei should continue to be the framework used to ground human rights and specify their realisation, is developed in five parts. The first identifies two understandings of dignity in the public realm, one inherent-transcendental, the other empirically verifiable. The second section compares the use of "dignity" in three traditions of Catholic Theological Ethics: virtue, natural law, and autonomy. In view of doubts whether theological anthropology should still be the primary location for expounding the meaning of imago Dei, the third section discusses attempts to absorb anthropology into ecclesiology. The modern history of reception of this biblical term by J.G. Herder is outlined in section four, before drawing conclusions from the previous enquiries for the question which language theological ethics should use in public discourse, imago Dei or dignity.
\end{abstract}

\section{Keywords}

contract - dignity - empirical - morality - transcendental - worldview

\section{Introduction}

The following enquiry into two alternative frameworks for social philosophy that affect judgements in domain-specific ethics is prompted by the question whether the concept of human dignity has to be assumed as a principle in order to determine and deliver on human rights. The backdrop to this examination is theological: Is the designation of the human being as made in the image of 
God a paradigm to be superseded, and thus the previous biblical foundation of the concept of human dignity to be accorded a place in the history of theological thinking, but now to be overcome in a search for more adequate terms? The aspects to be treated result in a five-part sequence, with the outer layer of parts 1 and 5 situated at the intersection of philosophical and theological ethics. First, the use of "dignity" in public discourse is analysed. It is divided into two approaches: an empirical and an intrinsic one (1). The fifth and final section takes up the question of which language theological ethics should use in the public realm: Should it speak in terms of human dignity which acts as a bridge-building idea to other worldviews and to morality as a shared human capability, or with the specifically biblical and theological concept for human life created as imago Dei (5)?

The inner sections 2, 3, and 4 deal with the theological and philosophical history of reception of this term and with the tasks it poses for interpretation and theory decisions within Christian thought. The second section analyses how human dignity is framed in three approaches to Catholic theological ethics - virtue, natural law, and autonomy (2). The third asks whether any other theological discipline apart from theological anthropology in which the biblical concept of imago Dei has been located so far could take over its function. Would this imply that the discipline of theological anthropology could be redistributed to other parts of theology? In view of current approaches to Christian ethics that programmatically replace anthropology with ecclesiology, I will discuss this option (3). Fourthly, the role of imago Dei in a philosophical reflection from the Enlightenment and Romanticism will be presented as a critical backdrop to contemporary self-understandings (4). Viewed from this prior history - the horizon of reflection elaborated at the beginning of classical modernity - the initial question has gained new contours. Does it make a difference for public opinion- and will formation which framework is adopted: a legal one marked by strict reciprocity, or the conception of an inherent endowment of human beings with dignity as a shared moral principle (5)?

Before outlining the two main current uses of "dignity" and the opposite anthropological consequences they lead to, key stations in the history of Christian thinking on humans as imago Dei should be briefly marked: (1) the biblical grounding in Genesis 1:26-27 when the newly created first ever human being is attributed the designation of being "made in the image and likeness of God", of which the normative consequence becomes evident a few chapters later: in the prohibition to spill the blood of fellow-humans since they, too, have been made in the image of God (Genesis 9:6); (2) the different lines of interpretation of "image" of and "likeness" to God, and the instructive difference in Patristic interpretations whether humans resemble God in their 
rationality, or in their freedom; (3) the consequences of this alternative for the understanding of intersubjectivity: if imago Dei is interpreted as freedom, in terms of will, rather than in terms of a cognitive Greek rationality, the inherent link to the recognition of others based on good will becomes clearer, and exclusion based on diminished rationality is not possible; ${ }^{1}$ or (4) the interdenominational dispute on whether the constitution as imago Dei could have been lost in the Fall, as Luther assumes, requiring a complete re-creation of the human person through God's justification. ${ }^{2}$ This theological question reappears in secular form in the controversy I will treat first, whether human dignity can be lost, and which interpretation is being presupposed by those who say it can.

\section{2 \\ Which Understanding of Dignity in the Public Realm?}

One of the debates in which it becomes evident that two different concepts of dignity are being used is the question of coercion at the end of life. One position understands "dignity" as an empirically verifiable state, based on criteria such as consciousness and independence. The related term "autonomy" is understood as self-determination, as the ability to choose what a person considers best for herself. In relation to the end of life, the demand to be able to "die with dignity" argues for the legalisation of physician-assisted suicide for patients who find their dignity compromised by the current conditions of their illness, which affects their wish to live. The alternative to this choice-based concept is a principled concept of dignity. It is expressed in the Council of Europe Recommendation 1418/99, "Report on the Protection of the Human Rights and Dignity of the Terminally Ill or Dying", that was accepted by a large majority of the Council in 1999 and has been endorsed in renewed debates several times since then. The following statements make it clear that "dignity" is not taken to indicate an empirical finding but a normative one:

1 Hans Reinders in his book, Receiving the Gift of Friendship, critiques the imago Dei tradition for this reason, that its empirically rational, cognitive understanding makes it discriminatory for persons with intellectual disabilities. This reading neglects, however, that there is an equally strong tradition of imago Dei as the human voluntative ability to respond to God, a relationship that cannot be verified empirically or ruled out as a possibility; it needs to be respected as much as the equally unprovable assumption of inner freedom.

2 More recently, Protestant systematic theologians have pointed out that this position is not biblical. It does not distinguish sufficiently between two levels: a foundational faculty (such as, as an example from another sphere, the ability for friendship), and its actualisation (in specific encounters and commitment to friends), erasing the distinction between a possible and an actual relationship to God. 
(3) [...] Dignity is a consequence of being human. Thus a condition of being can by no means afford a human being its dignity nor can it ever deprive him or her of it.

(4) [...] Pain, suffering or weakness do not deprive a human being of his or her dignity.

(5) [...] One possesses dignity and its subsequent rights not due to the recognition of other human beings, but due to one's descent from them.

(6) An individual's dignity can be respected or violated, yet it can neither be granted nor lost. Respect for human dignity is independent of factual reciprocity. Respect for human dignity is also due where reciprocity is not, not yet or no longer possible (i.e. towards patients in a coma). To believe that human dignity may be divided or limited to certain stages or conditions of life is a form of disregard for human dignity. ${ }^{3}$

This inherent concept contrasts with an empirically verifiable one where features like self-determination, absence of pain and of mental anguish are markers of dignity. It is the first, transcendental concept of dignity that has a pivotal function in the UDHR and the European Convention of Human Rights: as the source of human rights, as the basis for consensus formation on universal principles in pluralist societies, the supreme principle towards which all others are oriented and by which positive law is to be judged. In the empirical understanding, however, it is one right among others, assimilated to the liberal right to "privacy", as is expressed in the following quote from the Irish Council for Bioethics: The ІСв "is of the opinion that competent adults should have the right to prepare an advance directive, stemming from their right to selfdetermination and their related rights to bodily integrity, privacy and dignity." Dignity is one among several criteria, it is not the source of rights, and it is a quality derived from, not the foundation of, self-determination.

It is an empirical understanding of both dignity and autonomy as choice, not as deontological "self-legislation", that is prominent in public discourse, indicating a starting point that begins with the negative rights of the individual citizen over against the state and fellow-citizens. ${ }^{5}$ This liberal view leaves out

3 Council of Europe, "Explanatory Memorandum”, p. 4-6. cf. Virt, Damit Menschsein Zukunft hat, esp. pp. 239-252. On the distinction of a principled and relational understanding of "autonomy" from an empirical one, see the "Intervention" co-authored by feminist theological ethicists on the moral questions arising in some technologies of assisted reproduction: Ammicht-Quinn et al., "Women in the Practice of Reproductive Medicine", pp. 119-136.

4 Irish Council for Bioethics, Is it Time, p. 15.

5 In Was wollen wir können? Ethik im Zeitalter der Biotechnik, p. 484, Dietmar Mieth points out how a transcendental understanding of dignity protects against an understanding of life as being a matter for disposition. 
the regard for third parties who may be affected by a person's individual decisions concerning her own life. The viewpoint from which morality is reconstructed is legal, restricted to the minimal obligations demanded from liberal citizens; this makes it harder to account for the practical insight that as human beings people have far deeper obligations than as mere citizens who only have to follow civil law and are not expected to actively promote the other's flourishing. The strict reciprocity of the social contract tradition is security- and stability-oriented. Innovative, advocatory actions like taking the risk of peacemaking cannot be envisaged because this is an anticipatory action that might not be reciprocated. ${ }^{6}$

A principled concept of dignity based on the human "capability for morality" also recognizes the protection offered by the law, but goes further: ${ }^{7}$ It is foremost the agency of every fellow human that is owed support, requiring both the legal protection of scope for action, and personal initiatives to help. Herta Nagl-Docekal explains why: Without "scope (Freiraum) individuals are not able to realize their competence to act. This free space requires legal protection which can only be conceived in a stringent way by using the paradigm of contract; only under this premise can the same freedom be secured for all citizens." 8 But this level is not sufficient, and the relation of the individual's autonomy in the sense of moral self-legislation to the happiness of others has to be actively pursued both in what it prohibits and in what it calls for: "It is of the greatest importance that the connection of 'self-legislation' to happiness is not about one's own happiness but that of others", expressed in the "narrow" and the "wide" duties contained in the categorical imperative. Its demand to "always respect human beings as persons implies, on the one hand, the prohibition to instrumentalise them against their will, and, on the other, to offer support and promote their well-being." Instrumentalisation for one's own purposes means "robbing them of their innermost competence - to shape their own lives." Nagl-Docekal concludes that the "wide" sense of making available "means that enabling their self-determination" corresponds to "what social and development political conceptions call 'empowerment". ${ }^{9}$ Against this demanding moral view it becomes clear that reducing everyone's capability for morality to a legal framework of basic indifference is a trend that theological ethics together with deontological ethics are called to challenge. "Human rights"

6 Cf. the work of Helmut Peukert regarding a concept of transformational agency. Peukert, "Beyond the Present State of Affairs", pp. 421-435. Peukert, Science, Action and Fundamental Theology. Peukert, Bildung in gesellschaftlicher Transformation.

7 Kant, Groundwork of the Metaphysic of Morals (BA, 77), p. 102 et seq.

8 Nagl-Docekal, Innere Freiheit, p. 89.

9 Nagl-Docekal, Innere Freiheit, p. 97. 
can denote a minimalist understanding of what has to be protected, and the concept of dignity is needed to anchor a self-understanding where the ability to consider the impact of one's actions on the rights and happiness of others is taken as a starting point that draws on the agent's own moral motivation. ${ }^{10}$

Which concepts, symbols, and attitudes does Christian Ethics have at its discretion to counteract a growing orientation towards understanding also social interaction in terms of strict reciprocity, within the pre-set limits of a do ut des? ${ }^{11}$ Calculating the benefit of the outlay of time and energy and rationalising what should be spontaneous initiatives and fulfilling encounters into useful measures for advancement undermines actions based on good will; it leaves workplaces, social institutions and places of learning such as universities, and even primary relationships bereft of motivations that are more than self-serving. Insisting on complete equivalence of outlay and return as in the frameworks in which it is apt, namely economic and legal relations, has been recognized as disastrous from other perspectives: as a "colonisation of the lifeworld by the system". ${ }^{12}$ A concept of citizenship that expects voluntary, solidaric engagement for the good of the shared polity degenerates into the "transformation of the citizens of prosperous and peaceful liberal societies into isolated, self-interested monads who use their individual liberties exclusively against one another like weapons". ${ }^{13}$ From a cultural diagnosis that sees such trends as alarming one could consider this path as a highly effective way of undermining a consciousness of freedom as interaction between subjects who cannot demand, but invite and hope for the free response of the other. The erosion of a personal consciousness of freedom may be a reaction to the restriction of the scope for action in globalised technological cultures and to dwindling natural resources; it can also be attributed to the cultural loss of faith in a creator God who has made a world that offers scope for good developments forged by human collaboration, insight, and hopeful agency.

While dignity taken as an empirical feature can be lost, and is granted or withheld based on verifiable criteria, the contrasting transcendental philosophical account as well as the theological understanding of imago Dei insist

10 O'Neill, "Distant Strangers", pp. 186-202. She contrasts the question "What ought I do?" with "What ought I get?" and concludes that the "perspective of obligation is more directly connected to action" (pp. 198-200).

11 The French philosopher Paul Ricoeur points out the danger of a self-serving reciprocity in Rawls's contract argumentation in Theory of Justice (1971) in Ricoeur, The Just, pp. 36-57, pp. $5^{8-75}$, indicating the need to embed it in a pre-understanding of the Golden Rule in order to safeguard its "deontological intention" (p. $5^{6}$ ).

12 Habermas, Theory of Communicative Action, vol. II, p. 196, pp. 318-331, pp. 332-373.

13 Habermas, Between Naturalism and Religion, p. 107. 
on it as a foundation that cannot be lost, although it can be counteracted and violated. An empirical view sees "dignity" as a right among others and not as the source of rights. It is based on an equally empirically oriented contractual framework for human intersubjectivity. If this approach is to be regarded as a reduction that endangers the normative presuppositions of democracy, the question of how to strengthen principled understandings of dignity becomes urgent. The focus thus turns to what intellectual resources can be provided by religious traditions. In Christian Ethics, as one of the disciplines that emerged in the history of Christian thought and practice, a variety of starting points can be identified that account for some of the conflicts of interpretation on the heritage of imago Dei.

Depending on the approach chosen to develop the practical implications of the Christian message, dignity is understood differently. ${ }^{14}$

\subsection{Virtue Ethics}

For virtue ethics, it is not a key term, but in its Aristotelian origins, the status of justice as the prime virtue can be read as coming close to respecting dignity. Paul Ricoeur sees this highest virtue as comparable to the "good will" that is the foundation of Kant's concept of practical reason. It is the core of the "capability for morality" that is the foundation of human dignity. ${ }^{15}$

While promoting the virtue approach in Christian Ethics, James Keenan has cited a critique that virtue can be "introspective"16 in a sense that goes beyond the reflective, internal element which has to be assumed for all varieties of ethics. It could consist in agents within the virtue paradigm accessing problems to be resolved mainly in terms of their own virtuous integrity. This focus is in danger of leaving out the structural factors as well as the need for a process of judgement that draws on all four sources of theological ethics - the Bible, tradition as its history of reception, the normatively human, and individual sciences. In order to reach justified proposals for action, for example, regarding laws to protect the dignity of children in an age of digitisation, interdisciplinary analyses

14 In the second part of Junker-Kenny, Approaches to Theological Ethics, pp. 85-192, I analyse the following three and two further approaches, one based on worship and the other on feminist analyses.

15 Cf. Ricoeur, "Ethics and Human Responsibility", pp. 279-29o.

16 Keenan, "Virtue Ethics", p. 9o. 
are called for as well as conceptions of the normatively human. Highlighting the disposition to act on one's insights as crucial, however, provides a close connection between virtue and the good will of the agent.

\subsection{Natural Law}

Natural law is teleologically oriented towards goods and purposes, interpreting these in different eras, as revisionist natural law points out against its classical, physicalist understanding. However, even in this adapted form it may put forward an objectivist anthropology. If the worth of human life is measured by goals and purposes and if the "common good" is not specified by its link to human rights, ${ }^{17}$ there can be the danger of a Catholic utilitarianism. In order not to subsume individual basic rights to the common good, a concept of dignity is required. It is one of the principles of Catholic Social Teaching, which has enabled this tradition to endorse constitutions that are committed to this highest norm and overcome the anti-modernist critique of the state in its neutrality towards worldviews.

At the same time, its basis in a teleological naturalising anthropology leads to conflicts with an understanding of dignity based on principled autonomy. While it was a break-through for the Roman Catholic Church to move to endorsing human dignity in the Second Vatican Council's document Dignitatis humanae, this fundamental acceptance valid for each human being has been undermined by more recent Vatican documents proposing a specific "dignity of women". This runs counter to, and is incompatible with, the understanding of human dignity as general, that is, universal, as a concept that does not allow role allocations for gender, race, class, age, etc., as Mulieris dignitatem proposes for the female gender. As Herta Nagl-Docekal analyses, the term itself, "woman's dignity", is "a conception that fails to respect what it claims to uphold". 18

\subsection{Autonomy}

The advantage of the autonomy approach in Continental theological ethics is its position, shared with natural law, that moral insight is a universal human capability. The ground of obligation is human freedom. Religion comes in at a different level, that of the question of meaning. It arises from experiences of just initiatives not being reciprocated but thwarted. When acts based on

\footnotetext{
17 David Hollenbach provides this bridge in Hollenbach, The Common Good and Christian Ethics (2002) and in his chapter in the Cambridge Handbook of Human Dignity: Hollenbach, "Human Dignity in Catholic Thought", pp. 250-259.

18 Nagl-Docekal, “Issues of Gender in Catholicism”, p. 166.
} 
good intentions fail, the "happiness" deserved by moral agents is negated. This "antinomy of practical reason" leads Kant to the postulate of God. ${ }^{19}$

The autonomy approach insists more than the other two schools of thinking on the first person singular perspective of agents which is not replaceable by objectivising assessments. This is not "subjectivism" or "whim" but discernment through one's conscience as an irreplaceable part of moral judgement. ${ }^{20}$

Ecclesiology as a Replacement for Theological Anthropology?

Part of the internal process of interpretation within the Christian community has to be the relationship between its conceptions of the human person, the dignity of Jesus Christ, and the place of the church; all of these contribute to the Christian understanding of God in God's self-communication in the person of Jesus and of God's reign to be advanced in history. If theological anthropology is no longer seen to be the discipline or dogmatic treatise in which imago Dei, together with grace, sin and salvation, are examined, Christology and ecclesiology are possible other locations. It is true that St. Paul uses imago Dei specifically for the person of the redeemer and does not dwell on it as a property of every single human creature. But this finding is only part of the overall orientation for all humans to "put on Christ" who is identified as the "Second Adam" and cannot be seen as establishing an alternative to its use in theological anthropology. Authors from Irenaeus to Schleiermacher can be examined for their inclusion of Jesus Christ into an emerging history of development of the imago Dei designation. ${ }^{21}$

19 The awareness of the danger of absurdity, clearly developed in deontological ethics but much less in an ethics of the flourishing life, is a key reason why Continental theologians continue to discuss Kant's approach as compatible with Christian convictions. The antinomy of practical reason does not enjoy the same standing and level of interest in English-speaking Christian ethics. I have tried to outline its relevance for a public theology in Junker-Kenny, "What Scope for Ethics in the Public Sphere?", pp. 485-498.

20 After taking account of all the factors and positions put forward in a practical discourse, the validating authority, as H. Nagl-Docekal points out in Innere Freiheit, p. 85 , has to fall to the moral subjectivity of each participant, to avoid "heteronomous relations and a moral emptying of the subject". This critical comment towards discourse ethics from the unsurpassable vantage point of "inner freedom" can also be directed at schools of theological ethics that associate individuality with an atomistic concept of the human person which seems impossible to reconcile with social ethics. While given anthropological constants need to be rescued from the "physicalism" evident in papal statements, the revisionist natural law ethicist Richard Gula is also concerned about the reduction of moral judgements to "whim": Gula, Natural Law Today, p. 378. 
While these distinct dogmatic treatises are necessarily linked, a more radical systematic proposal is to replace anthropology as an enquiry in its own right. Going beyond Catholic social ethics to other current approaches, there are two movements that put forward an ecclesiology that absorbs the previously independent discipline of anthropology: Stanley Hauerwas's outline of Christian virtue, as well as its subsequent development into a worship-based form of Christian ethics, and Radical Orthodoxy's programme to supersede the division between the secular political order and the Christian tradition by the one encompassing foundation of the church. ${ }^{22}$

Hauerwas's tendency to replace human agency by the grace experienced in the church is not only conveyed in the titles and contents of articles such as, "The Church's One Foundation is Jesus Christ Her Lord; Or, In a World Without Foundations: All We Have is the Church." ${ }^{23}$ It is also the reason for questioning methods like the historical-critical examination of the Bible as part of a modern epistemology. Thus, hermeneutics, the discipline of understanding, is put up as an alternative to the "living hermeneutic" of the church: "Indeed, I suspect the project to develop general hermeneutical theories by some theologians is an attempt to substitute a theory of interpretation for the church."24 The historical-critical method is viewed negatively as an "adaptation of Enlightenment philosophy to interpret the Bible [...] as text, not Scripture, torn apart from the community of believers [...] that authorizes the Bible as Scripture." 25

These programmatic critiques accord two extraordinary tasks to the church: it has to carry the justificatory burden for the Bible as its property, "authorizing it as Scripture"; and it is supposed to replace in effect all of humankind as the addressee of God's self-revelation. The Protestant theologian Christofer Frey gives a nuanced assessment of Hauerwas's enterprise: "Due to this social dimension the church has to be one of the most important themes in Christian ethics. However, the church cannot replace human nature which still has to be presupposed", specifying in a footnote: "This has to be noted critically against Stanley Hauerwas, Christian Existence Today: Essays on Church, World and Living in Between". 26

\footnotetext{
22 The programme was first put forward by Milbank: Theology and Social Theory.

23 This is the title which Hauerwas has given to his contribution in a book he co-edited: Hauerwas/Murphy/Nation (eds): Theology Without Foundations, pp. 143-162.

24 Hauerwas, "The Church as God's New Language", p. 55, quoted in Siker: "Stanley Hauerwas", p. 117 .

25 Siker, "Stanley Hauerwas", p. 111.

26 Frey, “Konvergenz und Divergenz", p. 122.
} 
Both movements agree that the church has to be contrasted as a community of inherent peacefulness to liberal society and antagonistic, if not belligerent nation states. ${ }^{27}$ The price for developing ethics from liturgy or for accepting the Radical Orthodox view that theology is to replace human sciences such as sociology, however, is high: It narrows the basis of Christian ethics to two sources, the Bible and tradition; it abolishes the link to the general consciousness of truth that Catholic theology has always recognized as the lumen naturale; it gives up on communicability beyond the realm of the faithful, or those they recognize as belonging to the church. In addition, its pretended unity underplays conflicts, and it typically does not engage in the unavoidable task to argue within the whole contemporary Christian tradition for the validity of their view with regard to its sources in Bible and theology.

A more fruitful direction, in my view, is to take seriously the history of reception of biblical monotheism and to look beyond the boundaries of ecclesial Christianity to the cultures it helped create. This is what the following section takes up with regard to a classically modern reception of imago Dei, from which new impulses for the contemporary use of human dignity in public discourse can be gleaned.

A Philosophical Interpretation of imago Dei in the Modern Era

In Johann Gottlieb Herder's philosophical interpretation of the origins of a humanity endowed with language, itself diversified into multiple systems, two aspects are held together: the vulnerability of the human being visible in the defenceless state in which it is born, and the uniqueness of each. Three factors are identified: Born "naked and bare, weak and in need, shy and unarmed", 28 the child is helped towards its "spiritual birth" by learning and tradition, connecting it with its "parents, teachers, friends [...] countrymen and their forefathers; and lastly with the whole chain of the human race". ${ }^{29}$ The second typically human factor that makes the critical appropriation of culture on the path to "self-formation" possible is the use of "reason and experience". The third element necessary for becoming human is divine providence in educating humanity. As a proto-Romantic, Herder highlights the conception of being

27 For this view of the state and its alternative, the Christian church, cf. Cavanaugh, "Killing for the Telephone Company", and Cavanaugh, "Church".

28 Herder, On the Origin of Language, p. 107 et seq. quoted in Pannenberg, Anthropology, p. 43.

29 Herder, Outlines of a Philosophy of the History of Man, IX, p. 227-229, quoted in Pannenberg, Anthropology, p. 46. 
made in the image of God as an individualizing capacity. Each person is directed towards attaining his or her specific version of humanity. ${ }^{30}$ The Origin of Language makes it clear that whatever perfection (an abstract term) can be attained as the goal of human striving only exists in concrete diversity. What is normative is singularity; any streamlining or homogenisation would run counter to each human's call to realise the image of God that they are meant to be. At the same time, the integrity of the "voice of one's self" which Charles Taylor takes to be Herder's lasting, though not undisputed legacy, ${ }^{31}$ must be worked out in view of the tensions that exist in each human being in her originality and finitude. According to the Protestant theologian Hermann Timm's research on the turn of the Enlightenment into Romanticism, the sense of struggle within the self shows his proposal to be much closer to the Protestant experience of the individual as simul iustus ac peccator than to other influences. ${ }^{32}$ For Herder, the traces of being created in the image of God reveal themselves in crucial features of human relationships; ${ }^{33}$ the ideal of self-formation towards this image continues to depend on God's providence.

Which Language in the Public Sphere?

Which lessons can be drawn for Christian ethics from the connection between imago Dei and human dignity? Within theological discourse, my conclusions

$30 \quad$ Pannenberg comments: "Herder's recourse to the idea of the divine image seems thus to be an expression of his opposition to the idea of a human self-fulfillment through active self-enhancement. In order to realize their human destiny, their humanity, human beings remain dependent on the most varied influences from outside and on the harmonious contribution of these to the advancement of their humanity. Their disposition to be like God is therefore fulfilled only by God himself, through the operation of his providence $[. .$.$] The concept of the image of God is here not replaceable by anything else."$ Pannenberg, Anthropology, p. 53.

31 Taylor, Sources of the Self, p. 369. On p. 375, Taylor summarises and quotes Herder: "The differences are not just unimportant variations within the same basic human nature [...]. Rather they entail that each one of us has an original path which we ought to tread; they lay the obligation on each of us to live up to our originality. Herder formulated this idea in a telling image: [...]. 'Each human being has his own measure, as it were an accord peculiar to him of all his feelings to each other' [...]. Each person is to be measured by a different yardstick, one which is properly his or her own."

32 Cf. Timm, Gott und die Freiheit, p. 285 et seq., with reference to the influence of Hamann's Lutheranism.

33 It would be worth tracing Herder's turn away from a Spinozist conception of being part of a whole in favour of a renewed emphasis on difference and individuality, a change not sufficiently examined by Charles Taylor. 
from sections 2 to 4 are that this designation is worth defending as the key term of a Christian concept of the person. Theological anthropology is needed, more than ever, as a discipline that engages with current controversies on naturalising views of embodied human freedom, on equal access for current and future generations to the earth's resources, and on a diversity that is meant to be. It can certainly not be collapsed into ecclesiology which has other tasks to fulfil. But the decisive question to theological ethics is whether it should conceive of itself as an in-house exercise, or as a discipline at the intersection between religious and secular self-understandings that argues with reasons that can be generally justified in the public sphere. Its objections to reducing the social bond to a social contract, and of morality to legality, then, must be based on reasons that every believer and non-believer can share due to their equally original capability for morality. The theological ethicist Christoph Hübenthal sees a choice to be made by Christian ethics: either it sees itself as one among other lifeworld traditions of belonging and adopts a culturalist view of ethics; or it argues on deontological, universalist grounds for its conclusions. The biblical and theological background provides heuristic, intensifying, motivating, and relativizing insights, but the argument is at the normative level on the basis of principled autonomy as the shared platform of humans. If one aims at less, Christian ethics remains at the level of exchanges on worldviews, and cannot refute elitist, contemptuous or self-centred views of the "good"; after all, the "good" is only a formal category for all types of contents. ${ }^{34}$ If theological ethics were to argue with reasons that can be understood also by fellow-humans without a faith commitment, it would help discourage framing problems in terms of identities in competition. From its own recognition of all humans as imago Dei, it would help uncover a shared foundational commitment and motivation to support humans in their vulnerability: "If then it were possible to recognize in indignation, an eminently reactive feeling, a positive motivation, it would be the responsibility with regard to the fragile in its multiple forms". ${ }^{35}$

\section{Biography}

Maureen Junker-Kenny is Professor in Theology and Fellow of Trinity College Dublin. Her publications include Religion and Public Reason: A Comparison of the Positions of J. Rawls, J. Habermas and P. Ricoeur (De Gruyter, 2014);

34 Hübenthal, Grundlegung der christlichen Sozialethik, p. 368.

35 Ricoeur, "The Erosion of Tolerance", p. 199. See also Ricoeur, "Autonomy and Vulnerability" and Ricoeur, “The Difference", p. 72-9o, p. 187-197. 
Approaches to Theological Ethics. Sources, Traditions, Visions (T \& T Clark, 2019); co-ed. (with K. Viertbauer), European Journal of Philosophy of Religion, Special Issue 2019, "Habermas on Religion". Research interests: Religion and public reason, J. Habermas, P. Ricoeur, F. Schleiermacher and theology in Modernity, biomedical ethics.

\section{Bibliography}

Ammicht-Quinn, Regina/Bobbert, Monika/Haker, Hille/Heimbach-Steins, Marianne/ Kostka, Ulrike/Mensink, Dagmar/Schmedders, Mechthild/Schmidt, Susanna/ Schneider, Marlies: "Women in the Practice of Reproductive Medicine and in Bioethical Discourse - an Intervention", in: Erik Borgman/Maureen Junker-Kenny/ Janet Martin Soskice (eds): The New Pontificate. A Time for Change? [ = Concilium 42 (1/2006)], pp. 119-136.

Cavanaugh, William T.: "Killing for the Telephone Company", in: Modern Theology 20 (2004) pp. 243-273.

Cavanaugh, William T.: “Church", in: Peter Scott/William T. Cavanaugh (eds): The Blackwell Companion to Political Theology. Oxford: Blackwell, 2007, pp. 393-406.

Council of Europe: "Recommendation 1418/99, Explanatory Memorandum (Rapporteur Edeltraut Gatterer)", in: Biomedical Ethics 4 (1999), pp. 4-6.

Frey, Christopher: "Konvergenz und Divergenz von Ethik und Praktischer Theologie", in: Michael Welker/Friedrich Schweitzer (eds): Reconsidering the Boundaries between Theological Disciplines. Münster: LIT Verlag, 2005, pp. 113-122.

Gula, Richard: "Natural Law Today", in: Charles Curran/Richard McCormick (eds): Natural Law and Theology. Mahwah, NJ: Paulist Press, 1991, pp. 369-391.

Habermas, Jürgen: Theory of Communicative Action, Vol. 2: Lifeworld and System. A Critique of Functionalist Reason, trans. Th. McCarthy. Boston, MA: Beacon Press, 1987.

Habermas, Jürgen: The Future of Human Nature, trans. C. Cronin/H. Beister/M. Pensky. Cambridge: Polity, 2003.

Habermas, Jürgen: Between Naturalism and Religion, trans. C. Cronin. Cambridge: Polity Press, 2008.

Hauerwas, Stanley: Christian Existence Today. Essays on Church, World and Living in Between. Durham, NC: Labyrinth Press, 1988.

Hauerwas, Stanley: Murphy, Nancey/Nation, Mark (ed.): Theology Without Foundations. Religious Practice and the Future of Theological Truth. Nashville, TN: Abingdon Press, 1994.

Herder, Johann Gottfried: "Essay on the Origin of Language", in:Jean Jacques Rousseau and Johann Gottfried Herder: On the Origin of Language, trans. J.H. Moran/A. Gode. New York, NY: F. Ungar Publishing Co., 1967. 
Herder, Johann Gottfried: Outlines of a Philosophy of the History of Man, trans. T. Churchill. New York, NY: A.M.S. Press, 1966 [18oo].

Hollenbach, David: The Common Good and Christian Ethics. Cambridge: Cambridge University Press, 2002.

Hollenbach, David: "Human Dignity in Catholic Thought", in: Marcus Düwell/Jens Braarvig/Roger Brownsword/Dietmar Mieth (eds): Cambridge Handbook of Human Dignity. Historical Traditions, Philosophical Interpretations, Legal Implementation and Contemporary Challenges. Cambridge: Cambridge University Press, 2014, pp. $250-259$.

Hübenthal, Christoph: Grundlegung der christlichen Sozialethik. Versuch eines freiheitsanalytisch-handlungsreflexiven Ansatzes. Münster: Aschendorff, 2006.

Irish Council for Bioethics: Is it Time for Advance Healthcare Directives? Dublin: Irish Council for Bioethics, 2006.

Junker-Kenny, Maureen: Approaches to Theological Ethics. Sources, Traditions, Visions. London/New York, NY: T \& T Clark, 2019.

Junker-Kenny, Maureen: "What Scope for Ethics in the Public Sphere? Principled Autonomy and the Antinomy of Practical Reason", in: Christof Hübenthal (ed.): Theology and Reason in the Public Sphere, Special Issue, Studies in Christian Ethics 32 (2019), pp. 485-498.

Kant, Immanuel, Groundwork of the Metaphysic of Morals, trans. H.J. Paton. New York, NY: Harper, 1964.

Keenan, James: "Virtue Ethics”, in: Bernard Hoose (ed.): Christian Ethics. An Introduction. London: Cassell, 1998, pp. 84-94.

Mieth, Dietmar: Was wollen wir können? Ethik im Zeitalter der Biotechnik. Freiburg: Herder, 2002.

Milbank, John: Theology and Social Theory. Beyond Secular Reason. Oxford: Blackwell, 1990.

Nagl-Docekal, Herta: "Issues of Gender in Catholicism. How the Current Debate Could Benefit from a Philosophical Approach", in: Charles Taylor/José Casanova/ George F. McLean (eds): Church and People. Disjunctions in a Secular Age. Washington, D.C.: The Council for Research in Values and Philosophy, 2012, pp. $155^{-187 .}$

Nagl-Docekal, Herta: Innere Freiheit. Grenzen der nachmetaphysischen Moralkonzeptionen. Berlin/Boston, MA: De Gruyter, 2014.

O'Neill, Onora: “Distant Strangers, Moral Standing and Porous Boundaries", in: Bounds of Justice. Cambridge, Cambridge University Press, 200o, pp. 186-202.

Pannenberg, Wolfhart: Anthropology in Theological Perspective, trans. M. O'Connell. Philadelphia, PA: Westminster, 1985. 
Peukert, Helmut: Science, Action, Fundamental Theology. Towards a Theology of Communicative Action, trans. J. Bohman. Cambridge, MA: MIT Press, 1984 [German original 1976].

Peukert, Helmut: "Beyond the Present State of Affairs. Bildung and the Search for Orientation in Rapidly Transforming Societies", in: Journal of Philosophy of Education 36 (2002) pp. 421-435.

Peukert, Helmut: Bildung in gesellschaftlicher Transformation, ed. by Ottmar John/ Norbert Mette. Paderborn: Schöningh, 2015.

Reinders, Hans: Receiving the Gift of Friendship. Profound Disability, Theological Anthropology and Ethics. Grand Rapids, MI: Eerdmans Publishing, 2008.

Ricoeur, Paul: "The Erosion of Tolerance and the Resistance of the Intolerable", in: P. Ricoeur (ed.): Tolerance between Intolerance and the Intolerable. Providence/ Oxford: Berghahn Books, 1996, pp. 189-201.

Ricoeur, Paul: The Just, trans. D. Pellauer. Chicago, IL: University of Chicago Press, 2000. Ricoeur, Paul: "Ethics and Human Capability. A Response", in: John Wall/William Schweiker/David Hall (eds): Paul Ricoeur and Contemporary Moral Thought. London/New York, NY: Routledge, 2002, pp. 279-29o.

Ricoeur, Paul: Reflections on the Just, trans. David Pellauer. Chicago, IL: University of Chicago Press, 2007.

Siker, Jeffrey S. (ed.): Scripture and Ethics. Twentieth Century Portraits. New York, NY/ Oxford: Oxford University Press, 1997.

Taylor, Charles: Sources of the Self. The Making of the Modern Identity. Cambridge: Cambridge University Press, 1989.

Timm, Hermann: Gott und die Freiheit. Studien zur Religionsphilosophie der Goethezeit. Vol. 1, Die Spinozarenaissance. Frankfurt a.M.: Klostermann, 1974.

Virt, Günter: Damit Menschsein Zukunft hat. Theologische Ethik im Einsatz für eine humane Gesellschaft, ed. by Gerhard Marschütz/Gunter Prüller-Jagenteufel. Würzburg: Echter, 2007. 